\title{
Receptor Tyrosine Kinases: Legacy of the First Two Decades
}

\author{
Joseph Schlessinger \\ Department of Pharmacology, Yale University School of Medicine, New Haven, Connecticut 06520 \\ Correspondence: joseph.schlessinger@yale.edu
}

Receptor tyrosine kinases (RTKs) and their cellular signaling pathways play important roles in normal development and homeostasis. Aberrations in their activation or signaling leads to many pathologies, especially cancers, motivating the development of a variety of drugs that block RTK signaling that have been successfully applied for the treatment of many cancers. As the current field of RTKs and their signaling pathways are covered by a very large amount of literature, spread over half a century, I am focusing the scope of this review on seminal discoveries made before tyrosine phosphorylation was discovered, and on the early days of research into RTKs and their cellular signaling pathways. I review the history of the early days of research in the field of RTKs. I emphasize key early findings, which provided conceptual frameworks for addressing the questions of how RTKs are activated and how they regulate intracellular signaling pathways.

$T_{\mathrm{r}}^{\mathrm{h}}$ he family of cell-surface receptors designated receptor tyrosine kinases (RTK) received their name more that a decade after the same molecules were already known as the cell-surface receptors for insulin (insulin receptor), epidermal growth factor (EGFR), and many other growth factor receptors. Following the pioneering discoveries of nerve growth factor and epidermal growth factor (EGF; Levi-Montalcini and Booker 1960; Cohen 1962) and the establishment of the important roles of these two growth factors in the control of neuronal differentiation and cell proliferation in vivo and in vitro, it became clear that these cytokines bind specifically to cell-surface receptors. Insulin had already been discovered by this time, and had been applied successfully to treat diabetes patients since the early twentieth century. The re- sulting homogenous preparations of pure insulin enabled the quantitative characterization of insulin binding to its receptor on intact cells or to solubilized insulin receptor preparations using radiolabeled insulin (De Meyts et al. 1973). These studies greatly advanced understanding of the ligand binding characteristics of insulin receptor and, later on EGFR (Carpenter et al. 1975), including the establishment of negative cooperativity in insulin binding to its receptor expressed on the surface of living cells (De Meyts et al. 1973). Moreover, these studies shed important light on the dynamic nature of the cellular behavior of these receptors. The capacities of insulin receptor and EGFR to undergo ligand-dependent down-regulation and desensitization through receptor-mediated internalization and degradation (Carpenter and

Editors: Joseph Schlessinger and Mark A. Lemmon

Additional Perspectives on Signaling by Receptor Tyrosine Kinases available at www.cshperspectives.org

Copyright (C) 2014 Cold Spring Harbor Laboratory Press; all rights reserved; doi: 10.1101/cshperspect.a008912

Cite this article as Cold Spring Harb Perspect Biol 2014;6:a008912 


\section{J. Schlessinger}

Cohen 1976; Gordon et al. 1978; Schlessinger et al. 1978a,b; Carpentier et al. 1979; Haigler et al. 1979) were also established well before the realization that growth factors receptors are endowed with intrinsic protein tyrosine kinase activities (Fig. 1).

Progress was also made in elucidating the role of growth factors in normal embryonic development, wound healing, and pathological conditions such as cancer. Early studies in the 1960s and 1970s showed that growth factors play an important role in oncogenesis induced by retroviruses and in the proliferation of tumorderived cancer cells. Pioneering studies performed by Howard Temin $(1966,1967)$ showed that cancer cells need less insulin and serum growth factors for cell proliferation compared with normal cells, suggesting that cancer cells
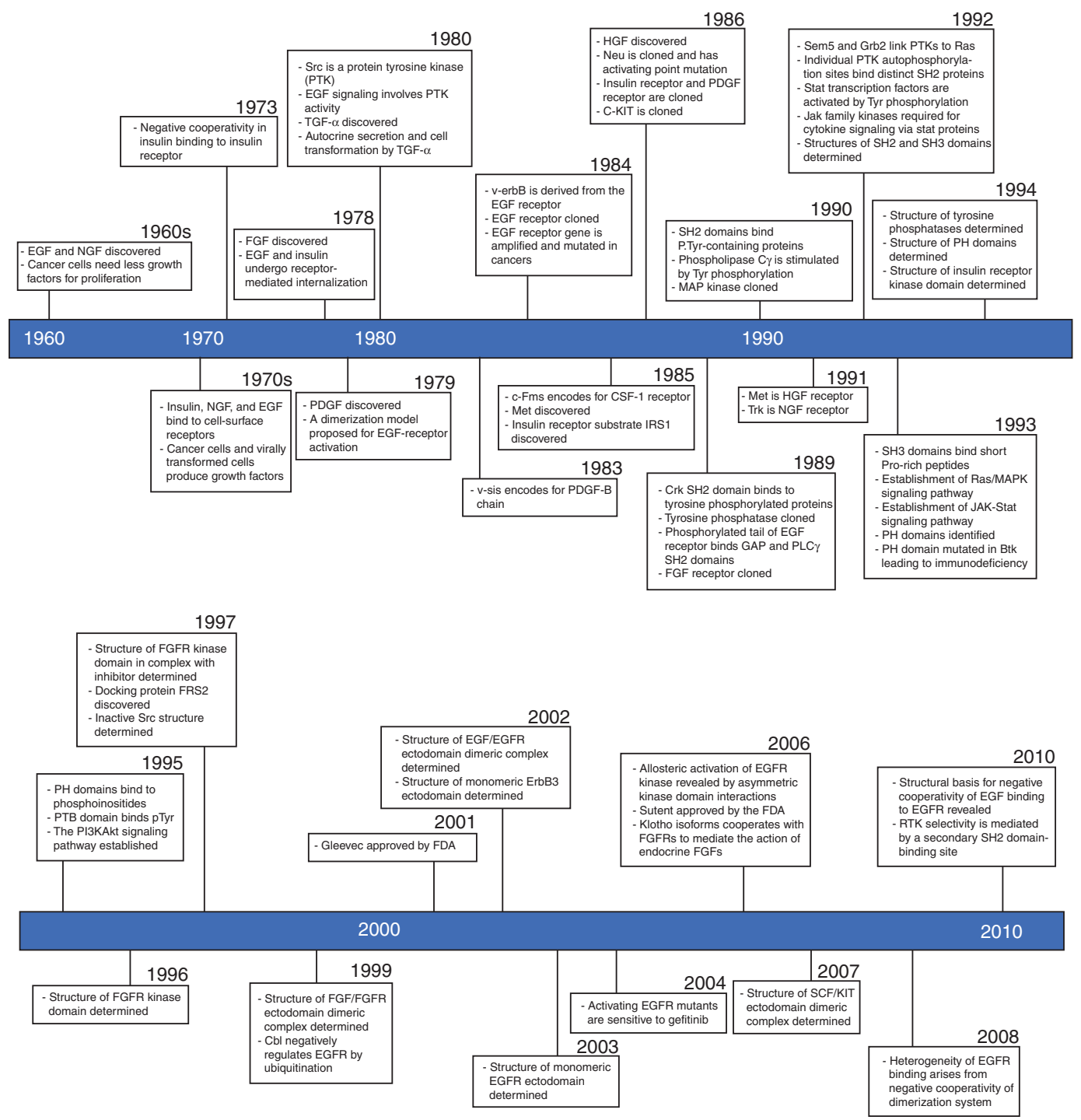

Figure 1. A time line of key findings during the history of RTKs, with emphasis on findings and discoveries that produced the conceptual framework in the development of the RTK field and its application for cancer therapy. References for the key findings are also presented in the text (Lee et al. 1985; Libermann et al. 1985; Margolis et al. 1990; Bottaro et al. 1991; Bae et al. 2009). 
produce and use their own growth factors and/ or use cellular processes that in normal cells are regulated by exogenously supplied growth factors; both predictions were subsequently confirmed. Avariety of new polypeptide growth factors that stimulate cell proliferation by binding to receptors at the cell surface were subsequently discovered. Those include a growth factor isolated from human platelets designated plateletderived growth factor (PDGF; Antoniades et al. 1979; Heldin et al. 1979), a growth factor isolated from bovine brain designated fibroblast growth factor (FGF; Gospodarowicz et al. 1978), a growth factor isolated from rat platelets that stimulates the proliferation of mature hepatocytes, designated hepatocyte growth factor (HGF; Nakamura et al. 1986). In addition to EGF, another growth factor that binds selectively to cells expressing EGFR was isolated from virally and chemically transformed cells, suggesting that this growth factor-designated transforming growth factor $\alpha$-may play a role in oncogenesis by an autocrine mechanism (Roberts et al. 1980, 1982). This discovery provided further support to the earlier finding that transformation by murine and feline sarcoma viruses selectively interferes with EGF binding to EGFR in transformed cells (Todaro et al. 1976). Together with many other studies published since the 1980s, this work showed that growth factors and their receptors play numerous important roles during development and in many normal cellular processes as well as in pathologies such as cancer, diabetes, atherosclerosis, severe bone disorders, and tumor angiogenesis.

Visualization of dynamic cellular redistribution of ligand/receptor complexes, and rapid receptor-mediated internalization of growth factors such as insulin or EGF, led to the proposal that cell-surface receptors for these ligands may play a passive role in delivering them to intracellular compartments in which internalized EGF or insulin molecules exert their actions (Vigneri et al. 1978; Podlecki et al. 1986; Jiang and Schindler 1990). In other words, according to this hypothesis, the biological signals induced by insulin or EGF were thought to be mediated by binding of the ligands themselves to intracellular target(s) in the cytoplasm or nucleus, with the role of the cell-surface receptor being to act as a "carrier" that delivers them directly to these targets. An alternative hypothesis was that insulin or EGF activates their cognate receptors at the cell surface, which in turn stimulate the production of an intracellular second messenger molecule analogous to cAMP in signaling by the Gprotein-activating $\beta$-adrenergic receptor. Indeed, several potential second messengers that are generated in cells on stimulation with insulin or other growth factors were proposed before (and even after) it became clear that insulin receptor, EGFR, and other RTKs are endowed with intrinsic tyrosine kinase activity (Larner et al. 1979; Das 1980; Saltiel and Cuatrecasas 1986).

A demonstration that anti-insulin receptor antibodies from the serum of certain diabetic patients could mimic cellular responses of insulin (Flier et al. 1977; Van Obberghen et al. 1979) provided the first conclusive answer to the question of whether the biological activity of growth factors is mediated directly or indirectly through their membrane receptors. This experiment ruled out the possibility that insulin receptor functions as a passive carrier that delivers insulin to an intracellular target to induce cellular responses. Studies showing that intact, bivalent antibodies against the insulin receptor can activate its signaling, whereas monovalent Fab fragments of the same antibodies cannot further argued that ligand-induced receptor dimerization or stimulation of a particular arrangement between two receptor molecules in a dimer can activate the insulin receptor (Kahn et al. 1978).

A similar conclusion was reached using certain monoclonal antibodies that bind to the extracellular region of EGFR and block ligand binding (Schreiber et al. 1981). Whereas intact antibodies were able to mimic EGF in stimulating a variety of EGF-like responses including cell proliferation, monovalent Fab fragments of the same monoclonal EGFR antibodies failed to do so-and acted instead as EGFR antagonists (Schreiber et al. 1981, 1983). These experiments provided strong evidence both that EGFR plays a crucial role in mediating EGF-induced cellular responses and that EGFR is activated by ligandinduced receptor dimerization (Schreiber 1981, 1983). 
J. Schlessinger

\section{GROWTH FACTOR RECEPTORS ARE ENDOWED WITH PROTEIN TYROSINE KINASE ACTIVITY}

Valuable insights into the mode of action of growth factors and their receptors were obtained from advancement in molecular characterization of the modes of action of retroviral oncogenic proteins. An interesting convergence of two different fields of biomedical research was taking place in the late seventies and early eighties, leading to the elucidation of mechanisms responsible for transformation of cells by a family of retroviral oncogenes. These studies led to the discovery of a common enzymatic activity used in controlling cell growth, and revealed the key features of how growth factors stimulate cell proliferation by binding to their cell-surface receptors.

The first key insight was provided by molecular characterization of the oncogene product, Src, from Rous sarcoma virus (Brugge and Erikson 1977). It was reported that Src is a protein kinase that phosphorylates primarily threonine residues (Collett and Erikson 1978). Subsequent experiments performed using lysates of EGF-stimulated human epidermoid carcinoma cells A431, which express very high levels of EGFR (more than two million copies) on their cell surface, similarly revealed EGF stimulation of threonine phosphorylation (Carpenter et al. 1978). A more thorough examination by Hunter and Sefton (1980) of the phosphorylation induced by the Src oncogenic product revealed that this was a unique kinase that phosphorylates tyrosines rather than serines or threonines. Subsequent studies revealed that EGFR stimulation also leads to phosphorylation of tyrosines, the mistake arising because phosphotyrosine (P-Tyr) and phosphothreonine (P-Thr) comigrate in the electrophoresis experiments performed at $\mathrm{pH} 1.9$ (Ushiro and Cohen 1980). It was also shown that the Abelson Leukemia virus protein, Abl, promotes tyrosine phosphorylation (Witte et al. 1980). Moreover, subsequent studies showed that treatment of cultured cells with PDGF or insulin-induced tyrosine phosphorylation. The fact that this was dependent on expression of platelet derived growth factor receptor (PDGFR) or insulin receptor, respectively, in the stimulated cells suggested that insulin receptor and PDGFR possess tyrosine kinase activity (Ek et al. 1982; Kasuga et al. 1982). Becasue tyrosine phosphorylation was seen with the oncogenic proteins Src and $\mathrm{Abl}$, as well as with growth factor-stimulated surface receptors such as EGFR, PDGFR, and insulin receptor strongly suggested that it plays an important role in normally regulated cell proliferation as well as in aberrantly stimulated proliferation of cancer cells, and that these proteins all activate a common enzymatic activity (i.e., protein tyrosine kinases).

Biochemical analysis of EGFR expressed in A-431 or other cultured cells showed that EGFR is a glycosylated, transmembrane receptor of molecular weight of $170 \mathrm{kDa}$, which is comprised of a large extracellular ligand binding region connected via a transmembrane domain to a cytoplasmic region that becomes phosphorylated on tyrosines on stimulation with EGF. However, in the absence of any direct information about the primary structure of EGFR and other members of the growth factor receptor family, it was not obvious whether the tyrosine kinase activity is encoded within the same gene that endows EGFR with specific EGF binding or whether the observed tyrosine kinase activity arises from a closely associated protein encoded by a separate gene. Other EGFR-associated activities were also reported. For example, a topoisomerase activity associated with purified EGFR - which leads to ATP-stimulated DNAnicking activity — was proposed to represent an intrinsic activity of EGFR or to become associated with EGFR during membrane solubilization (Miskimins et al. 1983; Mroczkowski et al. 1984; Basu et al. 1985). Further characterization of EGFR isolated from A-431 cells showed that the isolated EGFR can be recognized specifically by antibodies generated against certain synthetic peptides from the tyrosine kinase domain of Src, suggesting that the cytoplasmic region of EGFR may indeed contain a tyrosine kinase domain (Lax et al. 1984).

With the partial sequencing of peptides derived from human EGFR revealing a link between the retroviral oncogene v-erbB and the 
EGFR (Downward et al. 1984), and subsequent cloning of human EGFR cDNA that allowed the receptor's amino acid sequence to be deduced (Ullrich et al. 1984), the molecular nature of EGFR became clear. These findings showed that the EGFR contains a large extracellular ligand binding domain ( $\sim 620 \mathrm{aa})$, a single transmembrane helix, and a large $(\sim 540$ aa) cytoplasmic region that contains a tyrosine kinase domain. The tyrosine kinase domain is preceded by a short juxtamembrane region of $\sim 30$ aa that was later shown to play an important regulatory role, and is followed by a long carboxyterminal tail of $\sim 230$ aa that contains most of the tyrosine autophosphorylation sites (Downward et al. 1984; Ullrich et al. 1984). This molecular characterization also showed that the $\mathrm{v}$-erbB oncogene of the avian erthryoblastosis virus encodes a truncated avian EGFR that has lost most of the extracellular ligand-binding region as well as part of the carboxy-terminal tail containing tyrosine autophosphorylation sites. Importantly, these studies revealed that the retroviral oncogene v-erbB induces cell transformation by encoding an EGF-independent variant of avian EGFR that has constitutively stimulated tyrosine kinase activity (Downward et al. 1984; Ullrich et al. 1984; Kris et al. 1985).

This finding added to earlier studies that had revealed the first link between a retroviral oncogene and a growth factor, namely, the demonstration that the $v$-sis oncogene of simian sarcoma virus encodes the growth factor PDGF (Doolittle et al. 1983; Waterfield et al 1983). It was concluded that this virus had captured/ transduced the gene for a growth factor and the product of the retroviral $v$-sis oncogene induces cell transformation by autocrine stimulation of PDGFRs expressed on the surface of the same cells that secrete PDGF molecules (Doolittle et al. 1983; Waterfield et al. 1983).

\section{RTKs ARE ACTIVATED BY DIMERIZATION}

As previously mentioned, the central role of receptor dimerization as a mechanism of activation of insulin receptor and EGFR was revealed before these two receptors were defined as RTKs. A wealth of information accumulated during the late 1970s and early 1980s demonstrating that insulin or EGF stimulation leads to the clustering of insulin receptor or EGFR, respectively, on the cell surface. Moreover, the cellular responses of EGF or insulin could be stimulated by bivalent, but not by monovalent, receptor antibodies. Biochemical studies showed that, before ligand activation, EGFR is expressed on the cell surface as a monomer, whereas insulin receptor and the closely related IGF1 receptor are both expressed on the cell surface as preexisting disulfide linked dimers. It was also shown that the homodimeric structure of the inactive insulin receptor is essential for the negative cooperativity observed in binding of insulin to its receptor (De Meyts 2008).

The establishment of the primary structures of EGFR, PDGFR, and other RTKs showed that the ligand-binding region of RTKs is separated from the cytoplasmic region by a single transmembrane helix. The identification of the structural topology of EGFR and other monomeric RTKs triggered an intense debate about how ligand binding to an extracellular region transfers a stimulatory cue across the cell membrane to stimulate tyrosine kinase activity in the cytoplasmic region.

The two main mechanisms proposed for how EGF binding to the extracellular region stimulates the tyrosine kinase activity in the EGFR cytoplasmic region are presented in Figure 1. The top panel in Fig. 2A depicts an "intramolecular mechanism" in which EGF induces a conformational change in the extracellular region that is transmitted via the transmembrane helix to activate the tyrosine kinase domain in the cytoplasmic region. Accordingly, ligand-stimulated EGFR monomers transmit a structural change across the single transmembrane helix to activate the catalytic tyrosine kinase activity in cis and to mediate autophosphorylation on multiple tyrosine residues. In other words, according to this model, both tyrosine kinase activation and autophosphorylation are mediated by an intramolecular process (Bertics et al. 1985; Gill et al. 1987; Koland and Cerione 1988; Northwood and Davis 1988). 
J. Schlessinger
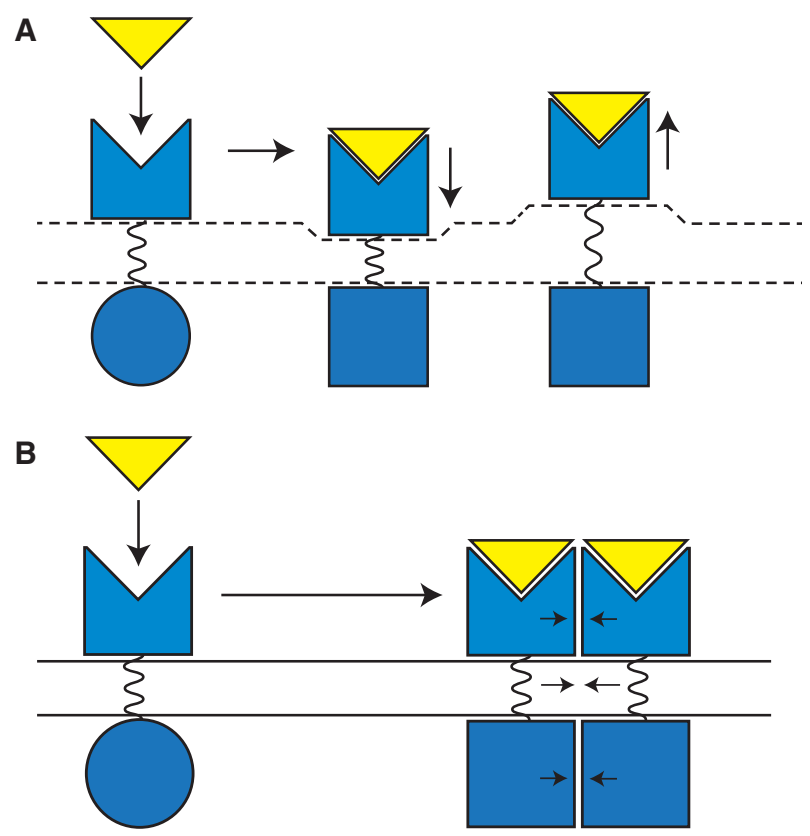

Figure 2. Two contrasting views during the early days for how EGF binding to the extracellular region of EGFR stimulates the tyrosine kinase domain in the cytoplasm. (A) An "intramolecular" mechanism. Ligand-stimulated EGFR monomers transmit a conformational change through the transmembrane helix to activate the tyrosine kinase domain and mediate autophosphorylation by an intramolecular process. $(B)$ An "intermolecular" mechanism. Ligand binding stimulates lateral contacts between a pair of EGFR molecules, resulting in EGFR dimerization mediated by interactions between extracellular regions, transmembrane domains, and cytoplasmic regions resulting in stimulation of tyrosine kinase activity and autophosphorylation by an intermolecular process.

The bottom panel (Fig. 2B) depicts an "intermolecular mechanism" for information transfer from the extracellular region to the cytoplasmic region, in which ligand binding induces lateral contacts between two receptors, resulting in their dimerization, which is responsible for stimulation of the tyrosine kinase activity and for autophosphorylation. Accordingly, both tyrosine kinase activation (Kashles et al. 1991) and tyrosine autophosphorylation are mediated in trans by an intermolecular process (Honegger et al. 1989).

It is now well established that dimerization or formation of larger oligomeric structures is required for activation of most, if not all, RTKs (Lemmon and Schlessinger 2010). Numerous cellular studies using advanced microscopic methods, as well as biochemical studies in cells and in vitro have shown that EGF promotes dimerization of its receptor. However, the preex- isting insulin receptor dimer provides an example in which ligand-induced dimerization per se is not required for signaling. Insulin activates its receptor by promoting an allosteric transition within this preexisting receptor homodimer (De Meyts 2008)—effectively stabilizing an active configuration of the dimeric receptor. An allosteric/dimerization model for ligand-induced stimulation of EGFR is shown in Figure $3 \mathrm{~A}$, which is modified from the original model described by Yarden and Schlessinger (1987). The model proposes that monomeric receptors are in equilibrium with receptor dimers. It is proposed that the monomeric receptor shows weak ligand-binding affinity and low or inactive tyrosine kinase activity. The dimeric receptor shows high ligand-binding affinity and elevated tyrosine kinase activity. $K_{D}$ is the dissociation constant for EGF binding to EGFR monomers and $K_{R}$ is the dissociation constant for EGF 
A
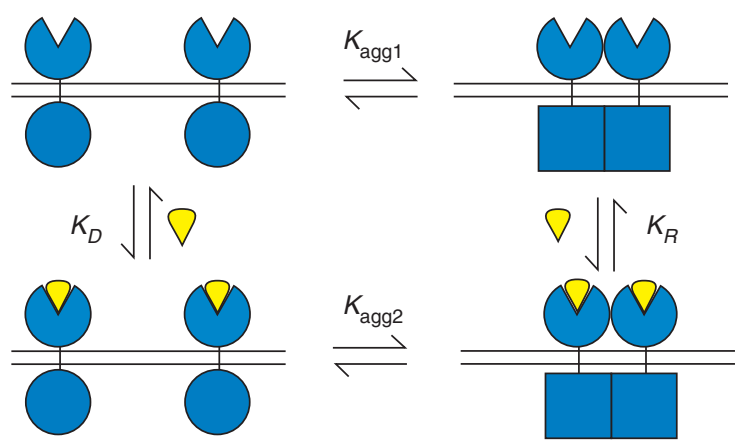

B

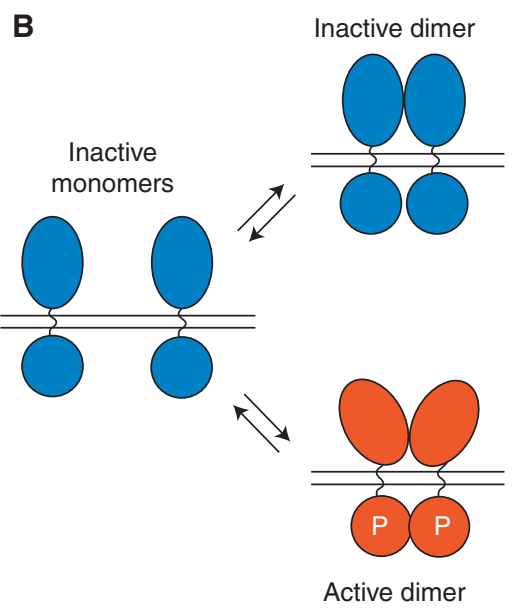

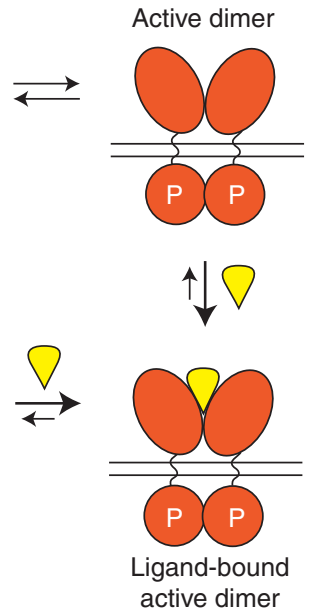

Figure 3. Models for ligand stimulation of RTK dimerization and activation. The scheme presented in $(A)$ is based on data from Yarden and Schlessinger (1987) with minor modifications. The scheme presented in $(B)$ is based on data presented in Schlessinger et al. (2000). This is a generalized allosteric/dimerization model for RTK activation that applies equally to EGFR and insulin receptor. Full details are presented in the body of the article.

binding to EGFR dimers. $K_{\mathrm{agg} 1}$ is the dimerization constant of EGFR monomers and $\mathrm{K}_{\mathrm{agg} 2}$ is the dimerization constant for EGFR dimers. It was previously shown that $K_{\mathrm{agg} 1} / K_{\mathrm{agg} 2}=K_{R}^{2} /$ $K_{D}^{2}$ (Yarden and Schlessinger 1987). According to this model, the enhanced binding affinity of EGF to dimeric EGFR confers the dimeric state on EGFR resulting in stimulated tyrosine kinase activity. For EGFR and many other RTKs, before ligand-binding monomers predominate-although this depends on the receptor expression level (Chung et al. 2010). For the insulin receptor, this equilibrium is shifted almost entirely to dimer even in the absence of ligand. The fact that the dimeric insulin receptor is not active until it binds ligand argues that dimerization-although required-is not necessarily sufficient for receptor activation. Instead, it is likely that "inactive" dimers are in equilibrium with "active" dimers as shown in Figure 3B. Ligand binding to an active dimer will stabilize it, whereas binding to an inactive dimer will induce a conformational change to promote activation (as seen for insulin and its receptor). In both cases, this ligand binding will pull the equilibrium to the right in Figure 3-constituting ligand-induced dimerization. The original model from 1987 assumed that the ligand-binding sites in the dimeric EGFR do not interact. More recent studies suggest that interactions between the 
J. Schlessinger

ligand-binding sites are responsible for the negative cooperativity and for the curvilinear Scatchard plots of EGF binding to EGFR in living cells (Alvarado et al. 2010; Pike 2012) —as is also well documented for the insulin receptor (De Meyts 2008). A generalized allosteric/dimerization model can be drawn for RTK activation that applies equally to EGFR and insulin receptor described by Schlessinger (2000) is presented in Figure 3B.

Although ligand stimulation of receptor by specific dimerization is a universal mechanism for RTK activation, different ligands use different strategies for stabilizing structural changes that are required for stimulation of tyrosine kinase activity.

\section{Dimeric RTKs Ligands}

The ligands of all type-III RTKs, including PDGFR, KIT, and other members of the family, are dimeric molecules. Structural studies have shown that binding of stem cell factor to the ligand-binding region in the ectodomain effectively "crosslinks" two KIT molecules, resulting in the formation of homotypic contacts between the membrane proximal regions of the ectodomains of receptor pairs (Yuzawa et al. 2007).

Ligand-Induced Receptor-Mediated Dimerization

Dimerization of EGFR and other members of the family is entirely mediated by receptor-mediated interactions. Ligand binding to individual protomers induces a conformational change in the extracellular region of EGFR that exposes a dimerization site that is occluded in the absence of ligand by autoinhibitory intramolecular interactions (Burgess et al. 2003).

\section{Ligand and Accessory Molecule-Mediated Dimerization}

FGF acts in concert with heparin sulfate proteoglycans to crosslink two fibroblast growth factor receptors (FGFRs). Direct contacts between FGF and heparin, FGF and FGFR, and heparin with FGFR mediate the formation of a sta- ble activated (2:2:2) FGFR-containing complex (Schlessinger et al. 2000).

Structural analysis of the free or ligand-occupied extracellular regions of EGFR, KIT, FGFR, and other RTKs as well as the analysis of the catalytic kinase domains of the insulin receptor, EGFR, and other RTKs provided valuable insights into the allosteric nature of the interactions that regulate them (Lemmon and Schlessinger 2010). Examples include asymmetric interactions between the tyrosine kinase domains of EGFR that provide a direct allosteric mechanism for tyrosine kinase activation (Zhang et al. 2006), asymmetric arrangement and partial ligand occupation of dimers of the Drosophila EGFR extracellular region, which provide a mechanism for negative cooperativity of EGF binding to EGFR (Alvarado et al. 2010; Pike 2012), asymmetric contacts between the tyrosine kinase domains of FGFR providing a potential mechanism for the ordered tyrosine autophosphorylation of FGFR (Bae et al. 2010), and structural insights into the role played by juxtamembrane domain of EGFR in the control of tyrosine kinase activity (Jura et al. 2009; Red Brewer et al. 2009).

\section{HOW TYROSINE PHOSPHORYLATION ACTIVATES CELLULAR SIGNALING PATHWAYS}

The mid 1990s saw a dramatic convergence of experimental insights obtained from biochemical, structural, and genetic studies that provided a molecular view of both how tyrosine phosphorylation regulates RTK activity and how tyrosine phosphorylation activates multiple signaling pathways to relay information from the cell membrane to the nucleus and other intracellular compartments. Intriguingly, regulation of the tyrosine kinases themselves (through autophosphorylation) is one of the most important roles of tyrosine phosphorylation of RTKs and nonreceptor protein tyrosine kinases (Hubbard et al. 1994). All tyrosine kinases contain 1-3 tyrosines in the activation loop of the catalytic core that, in most known cases, are the first tyrosine(s) to be phosphorylated following stimulation. Enzymatic analyses and 
structural studies have shown that autophosphorylation of these tyrosines maintains the activation loop in an "open" configuration permitting ATP binding to the nucleotide binding site and (by stabilizing the "active" conformation of the kinase) enabling transfer of the $\gamma$ phosphate to tyrosines of bound substrate molecules (Hubbard et al. 1994; Lemmon and Schlessinger 2010).

Inspection of the pattern of tyrosine phosphorylated cellular proteins following growth factor stimulation showed that, in most cases, the most strongly phosphorylated protein is the receptor of the stimulating growth factor. Most of the tyrosines that become autophosphorylated on RTKs are located in noncatalytic regions of the cytoplasmic domain, such as the juxtamembrane region (e.g., PDGFR and KIT), the kinase insert region (e.g., FGFR and KIT), or the carboxy-terminal tail. EGFR and other members of the ErbB family of RTKs become phosphorylated on multiple tyrosines located primarily in the carboxy-terminal tail of the receptor. One of the first clues as to how this autophosphorylation serves to propagate RTK signaling came from the finding that one substrate molecule that becomes phosphorylated in response to EGF stimulation, phospholipase $\mathrm{C} \gamma$ (PLC $\gamma$ ), also forms a stable complex with the activated receptor (Margolis et al. 1989; Meisenhelder et al. 1989). It was subsequently shown that complex formation between activated EGFR and PLC $\gamma$ is mediated by the Src homology 2 (SH2) domain of PLC $\gamma$ that binds directly to a P-Tyr site in the carboxy-terminal tail of EGFR (Margolis et al. 1990). The SH2 domain is a small protein module of $\sim 100$ aa, initially discovered as regulatory region in Src kinases responsible for maintaining tyrosine kinase activity of Src kinases in an inactive configuration by mediating intramolecular autoinhibitory interactions (Sadowski et al. 1986). Src, PLC $\gamma$, and many signaling proteins contain an additional small protein module designated the $\mathrm{SH} 3$ (for Src homology 3) domain, which binds specifically to short, proline-rich regions in target proteins (Pawson 1995, 2004). Interestingly, a viral oncogenic protein, designated Crk, does not contain any enzymatic activity, but only a single
SH2 domain followed by two SH3 domains (Matsuda et al. 1990). It was shown that in virally transformed cells, Crk forms complexes with several tyrosine-phosphorylated proteins (Matsuda et al. 1990). Importantly, it was shown that the SH2 domains of Crk bind directly to PTyr-containing proteins and peptides, suggesting that the biological role of $\mathrm{SH} 2$ domain of signaling molecules is to recognize P-Tyr sites within specific sequence contexts (Mayer and Hanafusa 1990; Matsuda et al. 1991; Pawson 2004; Waksman and Kuriyan 2004).

On the basis of these and other studies that are described in several review articles (Pawson 1995, 2004; Lemmon and Schlessinger 2010), it was established that a variety of $\mathrm{SH} 2$ domaincontaining signaling molecules, including enzymes such as PLC $\gamma$, the tyrosine phosphatase Shp2, and the GTPase-activating protein GAP for Ras, form complexes with activated EGFR and other RTKs by binding to specific P-Tyr sites in the receptor molecule. Complex formation with an activated RTK leads to efficient tyrosine phosphorylation of PLC $\gamma$, a step necessary for stimulation of its phospholipase activity (Lemmon and Schlessinger 2010). Additional proteins that form complexes with activated receptors include the small adaptor proteins Crk, Grb2, and Nck. These adapter proteins are composed entirely of $\mathrm{SH} 2$ and $\mathrm{SH} 3$ domains with architectures of SH2-SH3-SH3 for Crk, SH3$\mathrm{SH} 2-\mathrm{SH} 3$ for Grb2, and SH3-SH3-SH3-SH2 for Nck (Pawson 1995). Biochemical studies together with genetic screening in Drosophila and Nematodes have shown that Grb2 provides a link between RTKs and the Ras/Map kinase (MAPK) signaling pathway. Grb2 uses its SH2 domain for binding to the phosphorylated tail of activated EGFR and its two SH3 domains for recruitment of the nucleotide exchange factor, SOS, to provide a direct link between EGFR stimulation and the GTPase Ras (Pawson 2004; Lemmon and Schlessinger 2010). Activated Ras in turn stimulates a kinase cascade, ultimately leading to MAP kinase stimulation. Another example is the regulatory subunit, p85, of PI-3 kinase, which uses its $\mathrm{SH} 2$ domain to form a complex with activated RTKs leading to PI-3K activation (Pawson 1995, 2004). It was con- 
J. Schlessinger

cluded that RTKs function not only as enzymes but also as platforms for recruitment of a variety of signaling molecules that stimulate the activities of a variety of intracellular signaling pathways including the RAS/MAPK signaling pathway, the PI-3K/Akt signaling pathway, and the Jak2/STAT signaling pathways, among others.

Another mechanism for recruitment and activation of signaling molecules by activated RTKs involves docking proteins such as insulin receptor substrate 1 (IRS1) and other member of the IRS family and FGF receptor substrate 2 (FRS2). It was shown that docking proteins bind via their PTB domains to the insulin receptor or FGFRs, respectively, and become phosphorylated on numerous tyrosine. The P-Tyr sites of docking proteins provide a platform for the recruitment and activation of an additional complement of signaling molecules that bind to the P-Tyr sites of the docking proteins via their own $\mathrm{SH} 2$ domains (Lemmon and Schlessinger 2010), and are responsible for mediating many of the known insulin-induced cellular responses (see Boucher et al. 2014). The signaling pathways that are initiated at the cell membrane by activated RTKs and their specifically associated docking proteins are responsible for regulating many critical cellular processes essential for cell proliferation, cell differentiation, cell survival, and metabolism during development and normal homeostasis. Dysfunction in the activation or regulation of RTK stimulated signaling networks plays a critical role in a variety of human pathologies.

\section{ACKNOWLEDGMENTS}

I thank Mark Lemmon for his excellent suggestions for this work.

\section{REFERENCES}

${ }^{*}$ Reference is also in this collection.

Alvarado D, Klein DE, Lemmon MA. 2010. Structural basis for the negative cooperativity in growth factor binding to an EGF receptor. Cell 142: 568-579.

Antoniades HN, Scher CD, Stiles CD. 1979. Purification of human platelet-derived growth factor. Proc Natl Acad Sci 76: $1809-1813$.
Bae JH, Boggon TJ, Tomé F, Mandiyan V, Lax I, Schlessinger J. 2010. Asymmetric receptor contact is required for tyrosine autophosphorylation of fibroblast growth factor receptor in living cells. Proc Natl Acad Sci 107: 28662871.

Bae JH, Lew ED, Yuzawa S, Tomé F, Lax I, Schlessinger J. 2009. The selectivity of receptor tyrosine kinase signaling is controlled by a secondary $\mathrm{SH} 2$ domain binding site. Cell 138: 514-524.

Basu M, Frick K, Sen-Majumdar A, Scher CD, Das M. 1985. EGF receptor-associated DNA-nicking activity is due to a Mr-100,000 dissociable protein. Nature 316: 640-641.

Bertics PJ, Weber W, Cochet C, Gill CN. 1985. Regulation of the epidermal growth factor by phosphorylation. J Cell Biochem 29: 195-208.

Bottaro DP, Rubin JS, Faletto DL, Chan AM, Kmiecik TE, Vande Woude GF, Aaronson SA. 1991. Identification of the hepatocyte growth factor receptor as the c-met protooncogene product. Science 251: 802-804.

* Boucher J, Kleinridders A, Kahn CR. 2014. Insulin receptor signaling in normal and insulin-resistant states. Cold Spring Harb Perspect Biol doi: 10.1101/cshperspect. a009191.

Brugge JS, Erikson RL. 1977. Identification of a transformation-specific antigen induced by an avian sarcoma virus. Nature 269: 346-348.

Burgess AW, Cho HS, Eigenbrot C, Ferguson KM, Garrett TP, Leahy DJ, Lemmon MA, Sliwkowski MX, Ward CW Yokoyama S. 2003. An open-and-shut case? Recent insights into the activation of EGF/ErbB receptors. $\mathrm{Mol}$ Cell 12: 541-542.

Carpenter G, Cohen S. $1976 .{ }^{125}$ I-labeled human epidermal growth factor. Binding, internalization, and degradation in human fibroblasts. J Cell Biol 71: 159-171.

Carpenter G, King L Jr, Cohen S. 1978. Epidermal growth factor stimulates phosphorylation in membrane preparations in vitro. Nature 276: 409-410.

Carpenter G, Lembach KJ, Morrison MM, Cohen S. 1975. Characterization of the binding of ${ }^{125}$ I-labeled epidermal growth factor to human fibroblasts. J Biol Chem 250: 4297-4304.

Carpentier JL, Gorden P, Barazzone P, Freychet P, Le Cam A, Orci L. 1979. Intracellular localization of ${ }^{125}$ I-labeled insulin in hepatocytes from intact rat liver. Proc Natl Acad Sci 76: 2803-2807.

Chung I, Akita R, Vandlen R, Toomre D, Schlessinger J, Mellman I. 2010. Spatial control of EGF receptor activation by reversible dimerization on living cells. Nature 464: 783-787.

Cohen S. 1962. Isolation of a mouse submaxillary gland protein accelerating incisor eruption and eyelid opening in the new-born animal. J Biol Chem 237: 1555-1562.

Collett MS, Erikson RL. 1978. Protein kinase activity associated with the avian sarcoma virus src gene product. Proc Natl Acad Sci 75: 2021-2024.

Das M. 1980. Mitogenic hormone-induced intracellular message: Assay and partial characterization of an activator of DNA replication induced by epidermal growth factor. Proc Natl Acad Sci 77: 112-116. 
De Meyts P. 2008. The insulin receptor: A prototype for dimeric, allosteric membrane receptor? Trends Biochem Sci 33: 376-384

De Meyts P, Roth J, Neville DM Jr, Gavin JR III, Lesniak MA. 1973. Insulin interactions with its receptors: Experimental evidence for negative cooperativity. Biochem Biophys Res Commun 55: 154-161.

Doolittle RF, Hunkapiller MW, Hood LE, Devare SG, Robbins KC, Aaronson SA, Antoniades HN. 1983. Simian sarcoma virus onc gene, $\mathrm{v}$-sis, is derived from the gene (or genes) encoding a platelet-derived growth factor. Science 221: 275-277.

Downward J, Yarden Y, Mayes E, Scrace G, Totty N, Stockwell P, Ullrich A, Schlessinger J, Waterfield MD. 1984. Close similarity of epidermal growth factor receptor and v-erb$B$ oncogene sequences. Nature 307: 521-527.

Ek B, Westermark B, Wasteson A, Heldin CH. 1982. Stimulation of tyrosine-specific phosphorylation by plateletderived growth factor. Nature 295: 419-420.

Flier JS, Kahn CR, Jarrett DB, Roth J. 1977. Autoantibodies to the insulin receptor. Effect of the insulin-receptor interaction in IM-9 lymphocytes. J Clin Invest 60: 784-794.

Gill GN, Santon FB, Bertics PJ. 1987. Regulatory features of the epidermal growth factor receptor. J Cell Physiol 5: $35-41$.

Gordon P, Carpentier JL, Freychet P, LeCam A, Orci L. 1978, Intracellular translocation of iodine-125 labeled insulin: Direct demonstration in isolated hepatocytes. Science 200: $782-785$.

Gospodarowicz D, Bialecki H, Greenburg G. 1978. Purification of the fibroblast growth activity from bovine brain. Biol Chem 253: 3736-3743.

Haigler HT, McKanna JA, Cohen S. 1979. Direct visualization of the binding and internalization of a ferritin conjugate of epidermal growth factor in human carcinoma cells A-431. J Cell Biol 81: 382-395.

Heldin CH, Westermark B, Wasteson A. 1979. Plateletderived growth factor: Purification and partial characterization. Proc Natl Acad Sci 76: 3722-3726.

Honegger AM, Kris RM, Ullrich A, Schlessinger J. 1989. Evidence that autophosphorylation of solubilized receptors for epidermal growth factor is mediated by intermolecular cross-phosphorylation. Proc Natl Acad Sci 86: 925-929.

Hubbard SR, Wei L, Ellis L, Hendrickson WA. 1994. Crystal structure of the tyrosine kinase domain of the human insulin receptor. Nature 372: 746-754.

Hunter T, Sefton BM. 1980. Transforming gene product of Rous sarcoma virus phosphorylates tyrosine. Proc Natl Acad Sci 77: 1311-1315.

Jiang LW, Schindler M. 1990. Nucleocytoplasmic transport is enhanced concomitant with nuclear accumulation of epidermal growth factor (EGF) binding activity in both 3T3-1 and EGF receptor reconstituted NR-6 fibroblasts. J Cell Biol 110: 559-568.

Jura N, Endres NF, Engel K, Deindl S, Das R, Lamers MH, Wemmer DE, Zheng X, Kuriyan J. 2009. Mechanism for activation of the EGF receptor catalytic domain by the juxtamembrane segment. Cell 137: 1293-1307.

Kahn CR, Baird KL, Jarrett DB, Flier JS. 1978. Direct demonstration that receptor crosslinking or aggregation is important to insulin action. Proc Natl Acad Sci 75: 4209-4213.

Kashles O, Yarden Y, Fischer R, Ullrich A, Schlessinger J. 1991. A dominant negative mutation suppresses the function of normal epidermal growth factors by heterodimerization. Mol Cell Biol 11: 1454-1463.

Kasuga M, Zick Y, Blithe DL, Crettaz M, Kahn CR. 1982. Insulin stimulates tyrosine phosphorylation of the insulin receptor in a cell-free system. Nature 298: 667-669.

Klein R, Jing SQ, Nanduri V, O’Rourke E, Barbacid M. 1991. The trk proto-oncogene encodes a receptor for nerve growth factor. Cell 65: 189-197.

Koland JG, Cerione RA. 1988. Growth factor control of epidermal growth factor receptor kinase activity via an intramolecular mechanism. J Biol Chem 263: 2230-2237.

Kris RM, Lax I, Gullick W, Waterfield MD, Ullrich A, Fridkin M, Schlessinger J. 1985. Antibodies against a synthetic peptide as a probe for the kinase activity of the avian EGF receptor and v-erbB protein. Cell 40: 619-625.

Larner J, Galasko G, Cheng K, DePaoli-Roach AA, Huang L, Daggy P, Kellogg J. 1979. Generation by insulin of a chemical mediator that controls protein phosphorylation and dephosphorylation. Science 206: 1408-1410.

Lax I, Bar-Eli M, Yarden Y, Libermann TA, Schlessinger J. 1984. Antibodies of two defined regions of the transforming protein pp60src interact specifically with the epidermal growth factor receptor kinase system. Proc Natl Acad Sci 81: 5911-5915.

Lee DC, Rose TM, Webb NR, Todaro GJ. 1985. Cloning and sequence analysis of a cDNA for rat transformation growth factor- $\alpha$. Nature 313: 489-491.

Lemmon MA, Schlessinger J. 2010. Cell signaling by receptor tyrosine kinases. Cell 141: 1117-1134.

Levi-Montalcini R, Booker B. 1960. Excessive growth of sympathetic ganglia evoked by a protein isolated from mouse salivary gland. Proc Natl Acad Sci 46: 373-384.

Libermann TA, Nusbaum HR, Razon N, Kris R, Lax I, Soreg $\mathrm{H}$, Whittle N, Waterfield MD, Ullrich A, Schlessinger J. 1985. Amplification, enhanced expression and possible rearrangement of EGF receptor gene in primary human brain tumours of glial origin. Nature 313: 144-147.

Margolis B, Bellot F, Honegger AM, Ullrich A, Schlessinger J, Zilberstein A. 1990. Tyrosine kinase activity is essential for the association of phospholipase $\mathrm{C}-\gamma$ with the epidermal growth factor receptor. Mol Cell Biol 10: 435-441.

Margolis B, Li N, Kock A, Mohammadi M, Hurwitz DR, Zilberstein A, Ullrich A, Pawson T, Schlessinger J. 1990. The tyrosine phosphorylated carboxyterminus of the EGF receptor is a binding site for GAP and PLC- $\gamma$. EMBO J 9: 4375-4380.

Margolis B, Rhee SG, Felder S, Mervic M, Lyall R, Levitzki A, Ullrich A, Zilberstein A, Schlessinger J. 1989. EGF induces tyrosine phosphorylation of phospholipase C-II: A potential mechanism for EGF receptor signaling. Cell 57: 1101-1107.

Matsuda M, Mayer BJ, Fukui Y, Hanafusa H. 1990. Binding of transforming protein, $\mathrm{P} 47^{\text {gag-crk }}$, to a broad range of phosphotyrosine-containing proteins. Science 248: $1537-1539$.

Matsuda M, Mayer BJ, Hanafusa H. 1991. Identification of domains of the v-crk oncogene product sufficient for 
J. Schlessinger

association with phosphotyrosine-containing proteins. Mol Cell Biol 11: 1607-1613.

Mayer BJ, Hanafusa H. 1990. Association of the v-crk oncogene product with phosphotyrosine-containing proteins and protein kinase activity. Proc Natl Acad Sci 87: $2642-$ 2648.

Meisenhelder J, Suh PG, Rhee SG, Hunter T. 1989. Phospholipase C- $\gamma$ is a substrate for the PDGF and EGF receptor protein-tyrosine kinases in vivo and in vitro. Cell 57: $1109-1122$.

Miskimins R, Miskimins WK, Bernstein H, Shimizu N. 1983. Epidermal growth factor-induced topoisomerase(s). Intracellular translocation and relation to DNA synthesis. Exp Cell Res 146: 53-62.

Mroczkowski B, Mosig G, Cohen S. 1984. ATP-stimulated interaction between epidermal growth factor receptor and supercoiled DNA. Nature 309: 270-273.

Nakamura T, Teramoto H, Ichihara A. 1986. Purification and characterization of a growth factor from rat platelets for mature parenchymal hepatocytes in primary cultures. Proc Natl Acad Sci 83: 6489-6493.

Northwood IC, Davis RJ. 1988. Activation of the epidermal growth factor receptor tyrosine protein kinase in the absence of receptor oligermerization. J Biol Chem 263: 7450-7453.

Pawson T. 1995. Protein modules and signaling networks. Nature 373: 573-580.

Pawson T. 2004. Specificity in signal transduction: From phosphotyrosine-SH2 domain interactions to complex cellular systems. Cell 116: 191-203.

Pike LJ. 2012. Negative co-operativity in the EGF receptor. Biochem Soc Trans 40: 15-19.

Podlecki DA, Smith RM, Kao M, Tsai P, Huecksteadt T, Brandenburg D, Lasher RS, Jarett L, Olefsky JM. 1986. Nuclear translocation of the insulin receptor. J Biol Chem 262: $3362-3368$.

Red Brewer M, Choi SH, Alvarado D, Moravcevic K, Pozzi A, Lemmon MA, Carpenter G. 2009. The juxtamembrane region of the EGF receptor functions as an activation domain. Mol Cell 34: 641-651.

Roberts AB, Anzano MA, Lamb LC, Smith JM, Frolik CA, Marquadt H, Todaro GJ, Sporn MB. 1982. Isolation from murine sarcoma cells of novel transforming growth factors potentiated by EGF. Nature 295: 417-419.

Roberts AB, Lamb LC, Newton DL, Sporn MB, De Larco JE, Todaro GJ. 1980. Transforming growth factors: Isolation of polypeptides from virally and chemically transformed cells by acid/ethanol extraction. Proc Natl Acad Sci 77: 3494-3498.

Sadowski I, Stone JC, Pawson T. 1986. A noncatalytic domain conserved among cytoplasmic protein-tyrosine kinases modifies the kinase function and transforming activity of Fujinami sarcoma virus P130 gag-fps. Mol Cell Biol 6: 4396-4408.

Saltiel AR, Cuatrecasas P. 1986. Insulin stimulates the generation from hepatic plasma membranes of modulators derived from an inositol glycolipid. Proc Natl Acad Sci 83: 5793-5797.

Schlessinger J. 2000. Cell signaling by receptor tyrosine kinases. Cell 103: 211-225.
Schlessinger J, Plotnikov AN, Ibrahimi OA, Eliseenkova AV, Yeh BK, Yayon A, Linhardt RJ, Mohammadi M. 2000. Crystal structure of a ternary FGF-FGFR-heparin complex reveals a dual role for heparin in FGFR binding and dimerization. Mol Cell 6: 743-750.

Schlessinger J, Shechter Y, Cuatrecasas P, Willingham MC, Pastan I. 1978a. Quantitative determination of the lateral diffusion coefficients of the hormone-receptor complexes of insulin and epidermal growth factor on the plasma membrane of cultured fibroblasts. Proc Natl Acad Sci 75: 5353-5357.

Schlessinger J, Shechter Y, Willingham MC, Pastan I. 1978b. Direct visualization of binding, aggregation and internalization of insulin and epidermal growth factor on living fibroblastic cells. Proc Natl Acad Sci 75: 2659-2663.

Schreiber AB, Lax I, Yarden Y, Eshhar Z, Schlessinger J. 1981. Monoclonal antibodies against receptor for epidermal growth factor induce early and delayed effects of epidermal growth factor. Proc Natl Acad Sci 78: 75357539.

Schreiber AB, Libermann TA, Lax I, Yarden Y, Schlessinger J. 1983. Biological role of epidermal growth factor-receptor clustering. Investigation with monoclonal anti-receptor antibodies. J Biol Chem 258: 846-853.

Temin HM. 1966. Studies on carcinogenesis by avian sarcoma viruses. III: The differential effect of serum and polyanions on multiplication of uninfected and converted cells. J Natl Cancer Inst 37: 167-175.

Temin HM. 1967. Studies on carcinogenesis by avian sarcoma viruses. VI. Differential multiplication of uninfected and of converted cells in response to insulin. J Cell Physiol 69: 377-384.

Todaro GJ, De Larco JE, Cohen S. 1976. Transformation by murine and feline sarcoma viruses blocks binding of epidermal growth factor to cells. Nature 264: 26-31.

Ullrich A, Coussens L, Hayflick JS, Dull TJ, Gray A, Tam AW, Lee J, Yarden Y, Libermann TA, Schlessinger J, et al. 1984. Human epidermal growth factor receptor cDNA sequence and aberrant expression of the amplified gene in A431 epidermoid carcinoma cells. Nature 309: 418425.

Ushiro H, Cohen S. 1980. Identification of phosphotyrosine as a product of epidermal growth factor-activated protein kinase in A-431 cell membranes. J Biol Chem 255: 8363 8365.

Van Obberghen E, Spooner PM, Kahn CR, Chernick SS, Garrison MM, Karlsson FA, Grunfeld C. 1979. Insulinreceptor antibodies mimic a late insulin effect. Nature 280: $500-502$.

Vigneri R, Goldfine ID, Wong KY, Smith GJ, Pezzino V. 1978. The nuclear envelope. The major site of insulin binding in rat liver nuclei. J Biol Chem 253: 2098-2103.

Waksman G, Kuriyan J. 2004. Structure and specificity of the SH2 domain. Cell 116: S45-S48.

Waterfield MD, Scrace FT, Whittle N, Stroobant P, Johnsson A, Wasteson A, Westermark B, Heldin CH, Huang JS, Deuel TF. 1983. Platelet-derived growth factor is structurally related to the putative transforming protein $\mathrm{p} 28$ sis of simian sarcoma virus. Nature 304: 35-39.

Witte ON, Dasgupta A, Baltimore D. 1980. Abelson murine leukaemia virus protein is phosphorylated in vitro to form phosphotyrosine. Nature 283: 826-831. 
Yarden Y, Schlessinger J. 1987. Self-phosphorylation of epidermal growth factor receptor: Evidence for a model of intermolecular allosteric activation. Biochemistry 26: $1434-1442$.

Yuzawa S, Opatowsky Y, Zhang Z, Mandiyan V, Lax I, Schlessinger J. 2007. Structural basis for activation of the recep- tor tyrosine kinase KIT by stem cell factor. Cell 130: 323 334.

Zhang X, Gureasko J, Shen K, Cole PA, Kuriyan J. 2006. An allosteric mechanism for activation of the kinase domain of epidermal growth factor receptor. Cell 125: $1137-$ 1149. 


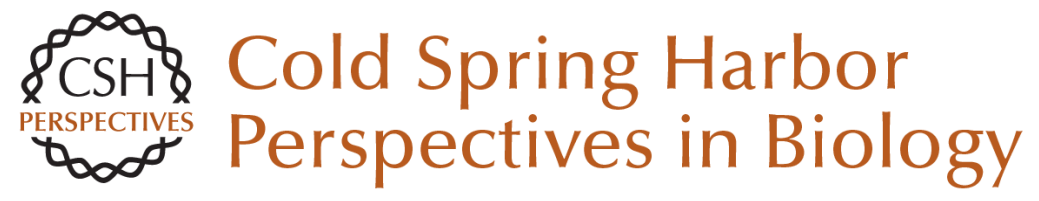

\section{Receptor Tyrosine Kinases: Legacy of the First Two Decades}

Joseph Schlessinger

Cold Spring Harb Perspect Biol 2014; doi: 10.1101/cshperspect.a008912

Subject Collection Signaling by Receptor Tyrosine Kinases

CSF-1 Receptor Signaling in Myeloid Cells

E. Richard Stanley and Violeta Chitu

The EGFR Family: Not So Prototypical Receptor Tyrosine Kinases

Mark A. Lemmon, Joseph Schlessinger and Kathryn M. Ferguson

Tie2 and Eph Receptor Tyrosine Kinase Activation and Signaling

William A. Barton, Annamarie C. Dalton, Tom C.M. Seegar, et al.

The Spatiotemporal Organization of ErbB

Receptors: Insights from Microscopy

Christopher C. Valley, Keith A. Lidke and Diane S. Lidke

Insulin Receptor Signaling in Normal and Insulin-Resistant States

Jérémie Boucher, André Kleinridders and C. Ronald Kahn

Central Role of RET in Thyroid Cancer Massimo Santoro and Francesca Carlomagno

Receptor Tyrosine Kinase-Mediated Angiogenesis Michael Jeltsch, Veli-Matti Leppänen, Pipsa Saharinen, et al.

Biology of the TAM Receptors Greg Lemke
The Genesis of Tyrosine Phosphorylation Tony Hunter

Structure-Function Relationships of ErbB RTKs in the Plasma Membrane of Living Cells

Donna J. Arndt-Jovin, Michelle G. Botelho and Thomas M. Jovin

Receptor Tyrosine Kinases: Legacy of the First

Two Decades Joseph Schlessinger

The Role of Ryk and Ror Receptor Tyrosine Kinases in Wnt Signal Transduction Jennifer Green, Roel Nusse and Renée van Amerongen

Regulation of Receptor Tyrosine Kinase Ligand Processing Colin Adrain and Matthew Freeman

Molecular Mechanisms of SH2- and PTB-Domain-Containing Proteins in Receptor Tyrosine Kinase Signaling Melany J. Wagner, Melissa M. Stacey, Bernard A. Liu, et al.

Eph Receptor Signaling and Ephrins Erika M. Lisabeth, Giulia Falivelli and Elena B. Pasquale

Effects of Membrane Trafficking on Signaling by

Receptor Tyrosine Kinases Marta Miaczynska

For additional articles in this collection, see http://cshperspectives.cshlp.org/cgi/collection/

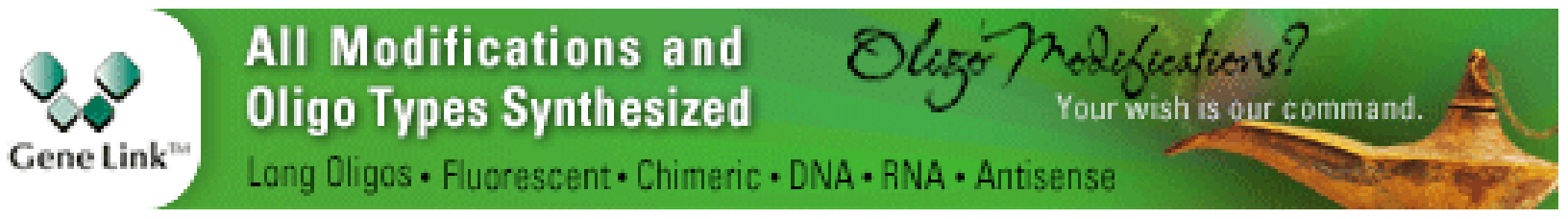


For additional articles in this collection, see http://cshperspectives.cshlp.org/cgi/collection/

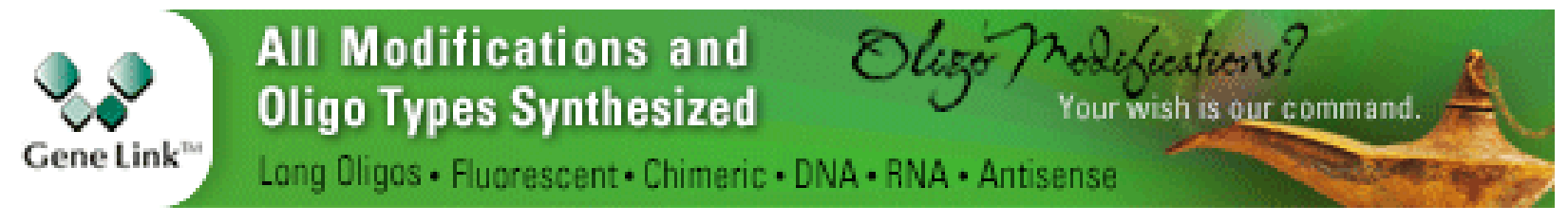

Copyright @ 2014 Cold Spring Harbor Laboratory Press; all rights reserved 